\title{
Is School Segregation Good or Bad?
}

\author{
By Federico Echenique, Roland G. Fryer, Jr., And Alex Kaufman*
}

Fifty years after the landmark Supreme Court decision in Brown v. Board of Education, racial disparities in achievement are a robust empirical reality. Black children enter kindergarten lagging behind white children, and these differences grow throughout the school years (James S. Coleman et al., 1966; Fryer and Steven D. Levitt, 2004). Even in affluent neighborhoods, achievement gaps are startling (Ronald F. Ferguson, 2002). Including myriad controls to proxy for environmental factors, socioeconomic status, and family composition, the test score gap remains essentially unchanged (Christopher Jencks and Meredith Phillips, 1998). The Brown decision provided unprecedented hope for a future of educational equality - a hope that has yet to be realized.

Many believe that the dramatic differences between blacks and whites in achievement are due, in part, to school segregation (Eric A. Hanushek et al., 2002). ${ }^{1}$ Since the Brown decision, there have been extensive efforts to integrate schools, though some of the initial progress has eroded in recent years (Gary Orfield, 2001).

There is an impressive literature on the effects of segregation across schools on achievement. Jonathan Guryan (2004) estimates that half of the decline in black drop-out rates between 1970 and 1980 is attributable to desegre-

\footnotetext{
* Echenique: The Division of Humanities and Social Sciences, California Institute of Technology, MC 228-77, Pasadena, CA 91125 (e-mail: fede@hss.caltech.edu); Fryer: Harvard Society of Fellows, 1875 Cambridge Street, Cambridge, MA 02138, and National Bureau of Economic Research (NBER) (e-mail: rfryer@fas.harvard.edu); Kaufman: Department of Economics, Harvard University, Cambridge, MA 02138 (e-mail: akaufman@fas.harvard.edu). We are grateful to Lawrence Katz and Glenn Loury for helpful comments and discussions. Katherine Barghaus and Patricia Foo provided exceptional research assistance. The usual caveat applies.

${ }^{1}$ Other explanations for the achievement gap range from the genetic inferiority of minorities (Richard J. Herrnstein and Charles Murray, 1994) to active discrimination on the part of teachers or schools (Elizabeth Haller, 1985).
}

gation plans. Robert Crain and Jack Strauss (1985) find that students randomly offered the chance to be bused to a suburban school were more likely to work in professional jobs nearly 20 years after the experiment. Based on a metaanalysis of 93 studies, Crain and Rita Mahard (1981) conclude that desegregation has a significant effect on black achievement, especially among younger children, though other metaanalyses are less conclusive (Nancy H. St. John, 1975).

In the spirit of Martin Luther King, who dreamed that one day "little black boys and black girls will be able to join hands with little white boys and white girls and walk together as sisters and brothers," some argue that society should strive for integration within schools not just across them (Roslyn A. Mickelson, 2001). Within-school segregation, commonly referred to as "secondgeneration segregation," is thought to be as important as segregation across schools in inhibiting the educational opportunities of racial and ethnic minorities (Mickelson, 2001).

We measure within-school segregation as the extent to which students interact socially with other students of the same race. Technically, the measure is an application of the "Spectral Segregation Index" (SSI), developed by Echenique and Fryer (2005). Previous studies use traditional measures of segregation (such as exposure and dissimilarity) to measure segregation across schools. These measures do not disaggregate to the individual level and do not use information on students' actual social contacts. Our paper is the first empirical study of the relationship between within-school racial segregation and outcomes.

\section{Measuring School Segregation}

In this section, we provide a skeletal derivation of the SSI developed in Echenique and Fryer (2005).

The basic building blocks for SSI are a set of individuals, $V$, who belong to the same race/ ethnicity, and information on whether any two 
individuals in $V$ interact. $^{2}$ Our measure identifies segregation of the members of a group with the intensity of the social interactions among the members of that group.

Given two individuals, $v$ and $v^{\prime}$ in $V$, let the number $r_{v v^{\prime}} \geq 0$ denote whether or not they interact socially. This paper uses data from a survey in which children were asked to name their ten closest friends. We say that $r_{v v^{\prime}}>0$ if $v$ names $v^{\prime}$ or $v^{\prime}$ names $v$ as one of her friends, and set $r_{v v^{\prime}}=1 / n$, where $n$ is the total number of friends of $v$ (including $v^{\prime}$ ). ${ }^{3}$ The basic economics underlying this assumption is that students have a budget constraint - they can spend one unit of time on social interactions-and absent any information on the intensity of any particular friendship, we weight them equally.

Let $B$ be a matrix with as many rows and columns as members of $V$, and typical entry $r_{v v^{\prime}}$. The matrix $B$ summarizes all the information on same-race interactions among the members of the race. Note that we still retain information about interactions with individuals of different races. For example, if $v$ interacts only with students of her race, then $v$ 's row in $B$ will have $n$ nonzero entries. If, on the other hand, $v$ interacts only with students of other races, her row will have only zero entries. This difference implies, according to our measure, that $v$ is more integrated when he has social relations with individuals of other races. ${ }^{4}$

A segregation index is a function that assigns a real number, $S(B)$, to each matrix $B$ of samerace interactions, along with functions assigning a real number, $s_{v}(B)$, for each individual member $v$ of $V$, such that $S(B)$ is the average of the individual $s_{v}(B)$.

Three properties jointly define our measure of segregation. The first property requires that an increase in same-race interactions lead to an increase in segregation. A matrix $B^{\prime}$ has more intense interactions than matrix $B$ if each individual $v$ has more friends $\left(r_{v v^{\prime}}>0\right)$ of her race

\footnotetext{
${ }^{2}$ This can be defined on any number of discrete groupings: race, gender, political affiliation, and so on.

${ }^{3}$ What is essential for our framework is that $r_{v v^{\prime}}>0$ if and only if $r_{v^{\prime} v}>0$; see Echenique and Fryer (2005). Adopting a more restrictive definition, $r_{v v^{\prime}}>0$ if and only if $v$ and $v^{\prime}$ list each other as friends, changes little.

${ }^{4}$ This feature, along with other ways to incorporate cross-race interactions, is discussed in detail in Echenique and Fryer (2005).
}

in $B^{\prime}$ than in $B$. Say that a segregation index satisfies the property of monotonicity if, whenever $B^{\prime}$ has more intense interactions than $B$, $S(B) \leq S\left(B^{\prime}\right)$.

The second property is a normalization of the index. A segregation index is homogeneous if, when all individuals in $B$ have exactly $n$ friends and $d$ same-race friends, $S(B)=d / n$.

We introduce some auxiliary concepts to present the third property. Let $N_{v}$ be the set of $v$ 's friends of her same race-her friends in $V$. In a similar vein, consider all friends (in $V$ ) of $v$ 's friends, and friends of friends of friends, and so on. The resulting set of individuals, with direct or indirect connections to $v$, is called the connected component of $B$ that $v$ belongs to; denote this set of individuals by $C_{v}$. Components can be interpreted as same-race cliques.

The third property says that $s_{v}(B)$ should be the average $s_{v^{\prime}}(B)$ among $v$ 's same-race friends, relative to the average segregation of the individuals in $v$ 's connected component. In symbols, if $S^{C_{v}}$ is the average segregation of individuals in $C_{v}$, a segregation index satisfies linearity if

$$
s_{v}(B)=\frac{1}{S^{C_{v}}} \sum_{v^{\prime} \in N_{v}} r_{v v^{\prime}} S_{v^{\prime}}(B)
$$

There are two qualitative assumptions behind the linearity property. The first is that $v$ 's segregation depends on her friends' segregation. This is the key innovation of the spectral index. The second is that the dependence is modulated by the connected component's segregation. A decrease in the segregation of one of $v$ 's friends will affect $v$ less if $v$ interacts with a highly segregated component. The idea is that $v$ receives the effects of segregation from her different friends, and any one friend is less important when the component is highly segregated.

The SSI is the (unique) segregation index that satisfies the properties of monotonicity, homogeneity, and linearity. ${ }^{5}$

\section{Data and Preliminary Analysis}

The National Longitudinal Study of Adolescent Health (Addhealth) database is a nationally representative sample of 90,118 students enter-

\footnotetext{
${ }^{5}$ Echenique and Fryer (2005) show how the three properties define an index uniquely.
} 

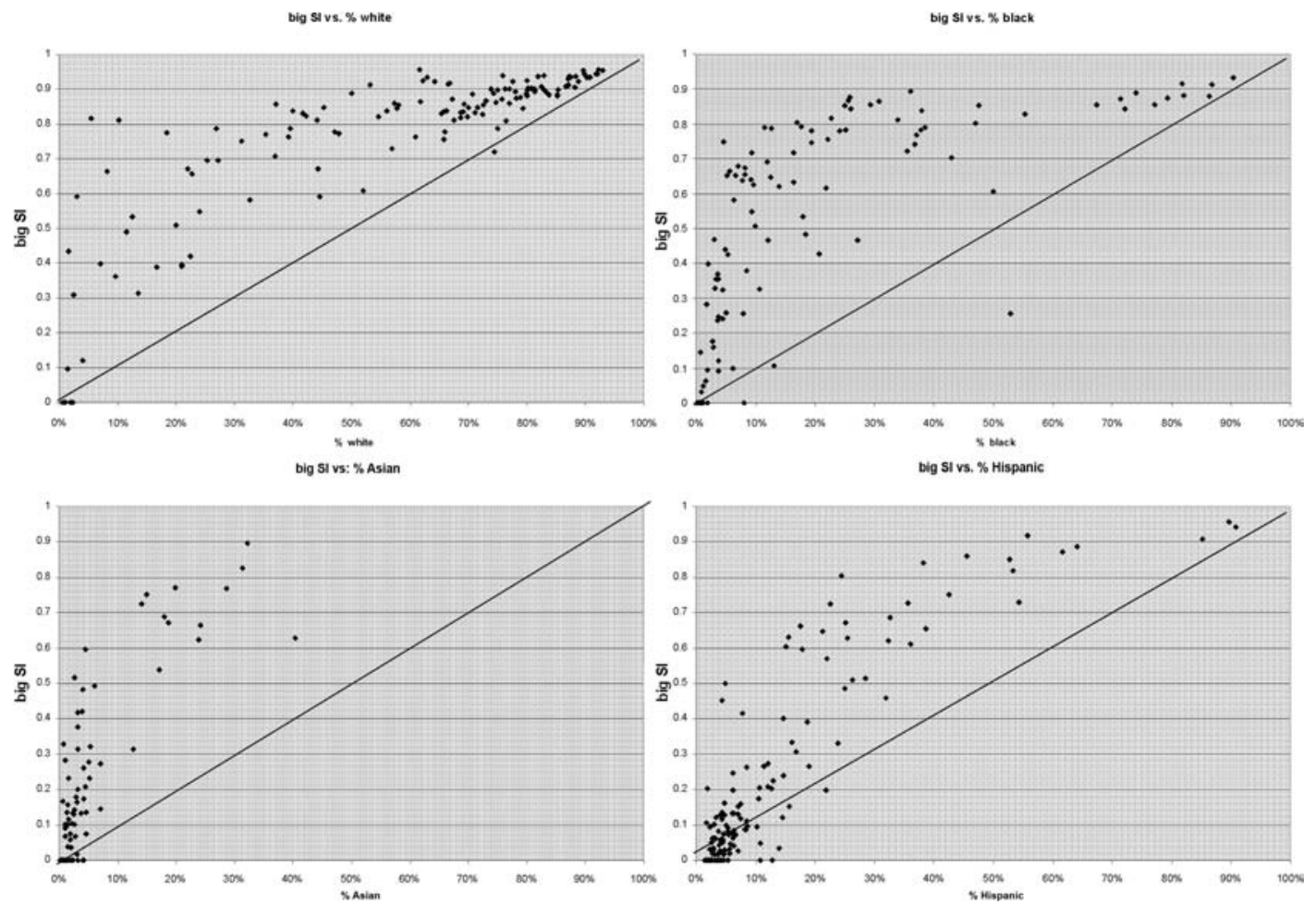

Figure 1. The Relationship between Group Size and Group Segregation, by Race

ing grades 7 through 12 in the 1994-1995 school year. A stratified random sample of 20,745 students was given an additional inhome interview. Information has been collected on these students at three separate points in time: 1995, 1996, and 2002. There are 175 schools from 80 communities included in the sample. Students who are missing data on race or grade level are dropped from the sample.

A wide range of data is gathered on the students, as described in detail on the Addhealth Web site (http://www.cpc.unc.edu/projects/ addhealth). Our primary outcome variables are divided between measures of academic achievement and those that are more associated with social behaviors. The social variables include smoking, skipping school (without a valid excuse), interracial dating, and whether or not a student is happy at school. Smoking and skipping school are answers to the question, "During the past 12 months, how often did you ...?" Answer choices range from never to nearly every day. Interracial dating is a dichotomous variable equal to one if the student reports ever dating interracially, and zero otherwise. Happiness measures whether or not students report being happy at their school. The academic variables include: Peabody Vocabulary Test (PVT) scores, whether or not a student plans to attend college, grades in the previous grading period, and a measure of how much effort the student exerts. All responses (including grades) are selfreported. For each student, grades were calculated by aggregating grades in four subjects: math, history, science, and English. ${ }^{6}$

Figure 1 depicts the relationship between the percentage of minority students in a school and the level of segregation for each minority student in that school. Each observation is a school. Grade levels 7 through 12 are combined.

Many researchers assume that the relationship between the segregation of a racial group within a school and the percentage of that group

\footnotetext{
${ }^{6}$ Details on the construction of these variables can be found in a Data Appendix posted at http://post.economics. harvard.edu/faculty/fryer/fryer.html.
} 
Table 1-The Relationship Between Individual Level Segregation and Outcomes

\begin{tabular}{|c|c|c|c|c|c|c|c|c|}
\hline & Smoking & $\begin{array}{l}\text { Skip } \\
\text { school }\end{array}$ & $\begin{array}{c}\text { Test } \\
\text { scores }\end{array}$ & $\begin{array}{l}\text { No } \\
\text { college }\end{array}$ & $\begin{array}{l}\text { Interracial } \\
\text { dating }\end{array}$ & Happiness & Grades & Effort \\
\hline \multirow[t]{2}{*}{ Black } & $-0.143 * *$ & $-0.010^{* *}$ & $-0.424 * *$ & $-0.013 *$ & $0.085^{* *} *$ & $-0.091 * *$ & $-0.216^{* *}$ & $0.027 *$ \\
\hline & 0.004 & 0.003 & 0.026 & 0.006 & 0.017 & 0.007 & 0.011 & 0.002 \\
\hline \multirow[t]{2}{*}{ Asian } & $-0.081 * *$ & $-0.008 *$ & $-0.303 * *$ & $-0.047 * *$ & $0.372 * *$ & $-0.025^{*}$ & $0.258 * *$ & $0.036^{* * *}$ \\
\hline & 0.006 & 0.004 & 0.042 & 0.007 & 0.029 & 0.010 & 0.015 & 0.003 \\
\hline \multirow[t]{2}{*}{ Hispanic } & $-0.040 * *$ & $0.026 * *$ & $-0.426^{* *}$ & $0.065 * *$ & $0.460 * *$ & $-0.016^{*}$ & $-0.182 * *$ & 0.003 \\
\hline & 0.005 & 0.003 & 0.026 & 0.006 & 0.017 & 0.007 & 0.010 & 0.002 \\
\hline \multirow{2}{*}{$\begin{array}{l}\text { Individual } \\
\text { segregation }\end{array}$} & 0.000 & 0.000 & 0.001 & 0.000 & $-0.007 * *$ & 0.000 & 0.001 & 0.000 \\
\hline & 0.001 & 0.000 & 0.003 & 0.001 & 0.002 & 0.001 & 0.001 & 0.000 \\
\hline \multirow{2}{*}{$\begin{array}{l}\text { Black* individual } \\
\text { segregation }\end{array}$} & $-0.003 *$ & -0.001 & $-0.025^{*}$ & 0.000 & -0.004 & 0.003 & 0.000 & 0.000 \\
\hline & 0.001 & 0.001 & 0.013 & 0.003 & 0.009 & 0.003 & 0.005 & 0.001 \\
\hline \multirow{2}{*}{$\begin{array}{l}\text { Asian* individual } \\
\text { segregation }\end{array}$} & -0.006 & $-0.008^{* *}$ & $-0.102 * *$ & 0.000 & $-0.067 * *$ & $0.021 * *$ & 0.017 & $0.004^{*}$ \\
\hline & 0.005 & 0.002 & 0.030 & 0.007 & 0.017 & 0.006 & 0.014 & 0.002 \\
\hline \multirow{2}{*}{$\begin{array}{l}\text { Hispanic* individual } \\
\text { segregation }\end{array}$} & $-0.006 *$ & -0.002 & $-0.047 * *$ & $0.012 * *$ & -0.015 & 0.004 & $-0.013 * *$ & $0.004 * *$ \\
\hline & 0.003 & 0.002 & 0.014 & 0.003 & 0.014 & 0.004 & 0.004 & 0.001 \\
\hline \multirow[t]{2}{*}{ Age } & $0.029 * *$ & $0.009 * *$ & $-0.034 * *$ & $0.021 * *$ & -0.002 & $-0.037 * *$ & $-0.024 * *$ & $-0.011^{* *}$ \\
\hline & 0.001 & 0.001 & 0.006 & 0.001 & 0.003 & 0.001 & 0.002 & 0.001 \\
\hline \multirow[t]{2}{*}{ Male } & -0.002 & $0.019 * *$ & $0.124 * *$ & $0.085 * *$ & 0.004 & $0.047 * *$ & $-0.184 * *$ & $-0.047 * *$ \\
\hline & 0.003 & 0.002 & 0.014 & 0.003 & 0.008 & 0.004 & 0.006 & 0.001 \\
\hline \multirow{2}{*}{$\begin{array}{l}\text { Mother college } \\
\text { educated }\end{array}$} & $-0.024 * *$ & -0.002 & $0.099 * *$ & $-0.080^{* *}$ & 0.001 & $0.031 * *$ & $0.154 * *$ & $0.006 * *$ \\
\hline & 0.004 & 0.002 & 0.019 & 0.004 & 0.010 & 0.005 & 0.008 & 0.002 \\
\hline \multirow{2}{*}{$\begin{array}{l}\text { Father college } \\
\text { educated }\end{array}$} & $-0.032 * *$ & $-0.010 * *$ & $0.078 * *$ & $-0.075^{* *}$ & 0.014 & $0.021 * *$ & $0.163 * *$ & $0.013^{* *} *$ \\
\hline & 0.004 & 0.002 & 0.021 & 0.004 & 0.012 & 0.005 & 0.008 & 0.002 \\
\hline \multirow[t]{2}{*}{ Mother professional } & -0.002 & -0.001 & $0.067 * *$ & $-0.024 * *$ & 0.011 & -0.006 & $0.062 * *$ & $0.003^{*}$ \\
\hline & 0.004 & 0.002 & 0.019 & 0.004 & 0.010 & 0.005 & 0.007 & 0.002 \\
\hline \multirow[t]{2}{*}{ Father professional } & $-0.008^{*}$ & 0.000 & $0.127 * *$ & $-0.048^{* *}$ & 0.018 & $0.022 * *$ & $0.114 * *$ & 0.001 \\
\hline & 0.004 & 0.002 & 0.020 & 0.004 & 0.011 & 0.005 & 0.008 & 0.002 \\
\hline \multirow[t]{2}{*}{ Constant } & $-0.220 * *$ & $-0.108 * *$ & $0.725 * *$ & $-0.125^{* *}$ & $0.117^{*}$ & $1.134 * *$ & $3.216 * *$ & $0.989 * *$ \\
\hline & 0.017 & 0.011 & 0.088 & 0.019 & 0.049 & 0.022 & 0.035 & 0.008 \\
\hline Observations & 78,075 & 77,903 & 14,387 & 69,257 & 9,553 & 73,837 & 72,744 & 79,599 \\
\hline$R$-squared & 0.07 & 0.04 & 0.28 & 0.1 & 0.37 & 0.05 & 0.18 & 0.08 \\
\hline
\end{tabular}

Notes: Dependent variables vary by column. In all cases, dummies for missing values are included. Robust standard errors are beneath the coefficients.

* Significant at 5-percent level.

** Significant at 1-percent level.

in the school is linear (see, for example, Orfield, 1983). This approximation is a good first pass for whites (though we find nearly all white data points above the $45^{\circ}$ line), but less true for Hispanics and Asians. For blacks, the relationship between percent own-race in a school and own-race segregation is even more nonlinear. As the percentage of black students increases from 0 to 25 percent, black segregation rises sharply. Above 25 percent, blacks are near complete segregation.

Table 1 presents estimates of individual-level measures of segregation on individual outcomes. We estimate models of the form

$$
\begin{aligned}
& \text { outcome }_{i}= X \beta+\text { ysegregation }_{i} \\
&+\xi_{1} \text { black } \text { segregation } \\
& i
\end{aligned}
$$

$$
\begin{aligned}
& +\xi_{2} \text { asian } \cdot \text { segregation }_{i} \\
& +\xi_{3} \text { hispanic } \text { segregation }_{i}+\varepsilon_{i},
\end{aligned}
$$

including school-level fixed effects. The coefficient $\gamma$ measures the relationship between the segregation of individual $i$ and a given outcome for $i$. In the forthcoming analysis, we concentrate on $\xi_{i}$, which measures the differential effect of individual segregation for group $i$ relative to whites, and $\gamma+\xi_{i}$, which captures the "raw" relationship between segregation and outcomes for group $i$, not relative to whites.

For blacks, individuals who are more segregated are less likely to smoke (a behavior predominant among white teens) and have lower test scores. Asian students who are 
more connected to each other are less likely to skip school and have lower test scores. They also put in more effort and report being happier. Among Hispanics, more segregation is associated with less smoking, lower test scores, lower probability of attending college, and lower grades. Interestingly, students of all races are less likely to date interracially when schools are more segregated. Similar results are obtained when one excludes school fixed effects.

\section{Conclusion}

It has been well documented that segregation across schools-denying access to resources, inferior educational production functions, and so on-exacerbates racial differences in achievement. Using an individual measure of social connections within schools, we have shown that this form of segregation-Asian kids sitting together in the cafeteria- has a substantively unimportant relationship with academic achievement or social behavior in school or later in life. There are important caveats to our analysis: (a) our estimates of the relationship between within-school segregation and outcomes are not causal; and (b) friendships may not be the only relevant cross-race social interaction that occurs within a school.

\section{REFERENCES}

Coleman, James S. "Equality of Educational Opportunity (Coleman) Study. U.S. Government Printing Office, 1966.

Crain, Robert L. and Mahard, Rita E. "Minority Achievement: Policy Implications of Research," in Willis D. Hawley, ed., Effective school desegregation: Equity, quality, and feasibility. Beverly Hills: Sage Publications, 1981, pp. 55-84.

Crain, Robert L. and Strauss, Jack. School desegregation and black occupational attainments: Results from a long-term experiment. Baltimore: Center for Social Organization of Schools, Johns Hopkins University, 1985.

Echenique, Federico and Fryer, Roland G., Jr. "On the Measurement of Segregation." National Bureau of Economic Research,
Inc., NBER Working Papers: No. 11258, 2005.

Ferguson, Ronald F. "A Diagnostic Analysis of Black-White GPA Disparities in Shaker Heights, Ohio," in Diane Ravitch, ed., Brookings papers on education policy 2001. Washington, DC: Brookings Institution Press, 2001, pp. 347-414.

Fryer, Roland G., Jr. and Levitt, Steven D. "Understanding the Black-White Test Score Gap in the First Two Years of School." Review of Economics and Statistics, 2004, 86(2), pp. 447-64.

Guryan, Jonathan. "Desegregation and Black Dropout Rates." American Economic Review, 2004, 94(4), pp. 919-43.

Haller, Elizabeth J. "Pupil Race and Elementary School Ability Grouping: Are Teachers Biased against Black Children?" American Educational Research Journal, 1985, 22(4), pp. 465-83.

Hanushek, Eric A.; Kain, John F. and Rivkin, Steven G. "New Evidence about Brown v. Board of Education: The Complex Effects of School Racial Composition on Achievement." National Bureau of Economic Research, Inc., NBER Working Papers: No. 8741, 2002.

Herrnstein, Richard J. and Murray, Charles. The Bell curve: Intelligence and class structure in American life. New York: Free Press, 1994.

Jencks, Christopher and Phillips, Meredith. "The Black-White test score gap: An introduction," in Christopher Jencks and Meredith Phillips, eds., The Black-White Test Score Gap. Washington, DC: Brookings Institution Press, 1998.

Mickelson, Roslyn A. "Subverting Swann: Firstand Second-Generation Segregation in the Charlotte-Mecklenburg Schools." American Educational Research Journal, 2001, 38(2), pp. 215-52.

Orfield, Gary. Public school desegregation in the United States, 1968-1980. Washington, DC: Joint Center for Political Studies, 1983.

Orfield, Gary. Schools more separate: Consequences of a decade of resegregation. Cambridge, MA: The Civil Rights Project, Harvard University, 2001.

St. John, Nancy H. School desegregation outcomes for children. New York: John Wiley \& Sons, 1975. 